\title{
Particulate matter analysis in indoor environments of urban and rural primary schools using passive sampling methodology
}

\author{
Nuno Canha ${ }^{\mathrm{a}, *}$, Susana Marta Almeida ${ }^{a}$, Maria do Carmo Freitas ${ }^{\mathrm{a}}$, Maria Trancoso ${ }^{\mathrm{b}}$, \\ Ana Sousa $^{\mathrm{b}}$, Filomena Mouro ${ }^{\mathrm{b}}$, Hubert Th. Wolterbeek ${ }^{\mathrm{c}}$ \\ ${ }^{a}$ C2TN, Instituto Superior Técnico, Universidade de Lisboa, EN 10, ao km 139.7, 2695-066 Bobadela LRS, Portugal \\ ${ }^{\mathrm{b}}$ Laboratório Nacional de Energia e Geologia, LNEG, UB, Laboratório de Biocombustíveis e Ambiente, Estrada do Paço do Lumiar, Edifício E, \\ 1649-038 Lisboa, Portugal \\ ${ }^{c}$ Department of Radiation, Radionuclides and Reactors, Faculty of Applied Sciences, Delft University of Technology, Mekelweg 15, \\ 2629 JB Delft, The Netherlands
}

\section{H I G H L I G H T S}

- Passive sampling methodology for particulate matter in indoors is proposed.

- Autumn was the season that presented higher particle masses concentrations.

- Calcium is the major indoor PM component in rural and urban classrooms.

- Soil re-suspension, traffic and chalk are the main sources of indoor PM.

- Natural ventilation is a major contributor to the variability of indoor PM.

\section{A R T I C L E I N F O}

\section{Article history:}

Received 27 May 2013

Received in revised form

24 October 2013

Accepted 28 October 2013

\section{Keywords:}

Indoor air quality

Primary schools

Particulate matter

Passive method

Source apportionment

Enrichment factors

\begin{abstract}
A B S T R A C T
Passive sampling methodology was applied to collect particulate matter (PM) in classrooms of urban and rural primary schools. The samples were taken during a year by passive deposition allowing the study of seasonal variability of the particles masses and chemical content. Chemical characterization of the collected particles was performed in order to measure its soluble ions content and elemental composition. To identify the main polluting sources, correlations between parameters and enrichment factors were studied. Higher particle masses concentrations were registered in autumn, with a mean of $1.54 \pm 0.74 \mu \mathrm{g} \mathrm{day}^{-1} \mathrm{~cm}^{-2}$. The major element in the collected particles was calcium, representing $63-73 \%$ of the analyzed mass of the particles inside the urban classrooms. In the rural cluster, calcium remained the major component but with a slight lower contribution to the overall particles composition (42-46\%). The calcium source was hypothesized to be the chalk used in the blackboards of the classrooms due to a strong correlation found between $\mathrm{Ca}^{2+}$ and $\mathrm{SO}_{4}^{2-}$. Soil re-suspension, traffic and other anthropogenic emission sources were also identified. Analysis showed enrichment of the particles with $\mathrm{Br}, \mathrm{Ca}, \mathrm{Zn}$ and $\mathrm{Sb}$ in the urban cluster and enrichment of the same elements, except for $\mathrm{Ca}$, in the rural cluster. The comparison between the results from both clusters allowed the identification of classrooms with higher particles concentrations that can indicate potential indoor air quality problems (reflected by an indoor accumulation of pollutants).
\end{abstract}

(c) 2013 Elsevier Ltd. All rights reserved.

\section{Introduction}

Over the last decade, several studies have been conducted to assess the indoor air quality in schools since the importance of the indoor air quality concerning health, performance and students attendance have been demonstrated (Mendell and Health, 2005).

\footnotetext{
* Corresponding author.

E-mail address: nunocanha@ctn.ist.utl.pt (N. Canha).
}

In fact, children spend most of their time in indoor environments leading them to a higher exposure to indoor pollutants than outdoor ones. Additionally, children breathe higher air volumes when compared to their body weight and have a lower capacity to deal with toxic chemicals, which consequently enhances their susceptibility to potential health consequences due to indoor air contaminants (Stranger et al., 2008; Selgrade et al., 2007; Canha et al., 2012a).

Health implications due to atmospheric particles pollution have been shown by epidemiological studies where correlations were 